\title{
THE SAGE AND THE TREE: ENVIRONMENTAL ETHICS IN LEKHNATH POUDYAL'S TARUN TAPASI
}

\section{BIKASH SHARMA}

Assistant Professor, Department of English, Sikkim Government College, Gyalshing, India

\begin{abstract}
Ecocriticism is a relatively new field of literary inquiry which has gained immense currency in the present age with questions of environmental damages occupying centre stage. It offers new and useful insights and goes a long way in addressing current ecological problems. However, great literary minds tend to presage events much before they unfold. In a similar vein, Leknath Poudyal's Tarun Tapasi forewarns the disastrous consequences entailing rash and thoughtless human encumbrance. Writtenin the 1950's, this poem predates much of the ecocritical theoretical perspectives and presents nature as an affected speaking voice. This epic fuses eastern Vedic philosophy with modern ecocritical awareness in order to highlight the nature-culture divide as a root cause of modern day ecological crisis.

KEYWORDS: Ecocriticism, Nature, Culture \& Ecological Problems
\end{abstract}

Received: May 11, 2020; Accepted: Aug 07, 2020; Published: Aug 20, 2020; Paper Id.: IJELAUG20204

\section{INTRODUCTION}

The multifariousness of literary theories in the twentieth century and beyond has ushered in a new age of diverse interpretive techniques. The American school of New Criticism, Russian Formalism, Structuralism, Poststructuralism or deconstruction, the list comes off as nearly inexhaustible. Add to this, the feminist, postcolonial and the comparatively recent ecocritical concerns and one is certainly risking a delicate swirl which may lead to (if one may use the Derridian jargon) 'aporia'. The 1990s saw the emergence of Ecocriticism - a relatively new yet the most rapidly emerging field of literary study which attempts to investigate the relationship between literature and the natural world. Cheryll Glotfelty in the editor's note to the Ecocriticism Reader: Landmarks in Literary Ecology states that "just as feminist criticism examines language and literature from a gender-conscious perspective, and Marxist criticism brings an awareness of modes of production and economic class to its reading of texts, ecocriticism takes an earth-centred approach to literary studies". Ecocriticism is based on a simple premise that literature both reflects and shapes human attitude towards the physical environment. A close analysis of the representation of the physical world in works of literature and the contexts in which they are produced and received can help us to arrive at an understanding of attitudes, practices and world view that have been the cause of modern-day environmental crisis having catastrophic humanitarian consequences like oil spills in Oceans, forest fires, deforestation, ozone layer depletion, global warming, pollution of all sorts, to name a few. As a field of literary inquiry, ecological criticism or ecocriticism as it is now commonly known - investigates literature in relation to the histories of ecological or environmentalist thought, ethics and activism. That is to say, environmental critics explore how nature and the natural world are imagined through literary texts. This paper is a modest attempt at examining Lekhnath Poudyal's Tarun Tapasi (The Young Ascetic) from an eco-critical perspective. However, it needs to be stated at the outset that owing to the unavailability of English translation of the work most of the stanzas used as way of illustration in this paper are my own translations. 
Leknath Poudyal, Nepal's crown-jewel poet, is one of the most prolific modern Nepali writers. Born in the year 1885 in Kaski, Nepal, Poudyal emerged as a successful modern Nepali poet, short story writer, playwright and essayist. The towering achievement of Poudyal's life can be found in works like Pinjadako Suga (A Parrot in a Cage), Ritu Vichara (Contemplation of the Seasons), Buddhi Vinoda (Enjoyments of Wisdom), Satya-Kali Samveda (A Dialogue between the Degenerate Age and the Age of Truth) and above all his magnum opus Tarun Tapasi (The Young Ascetic).

Tarun Tapasi (The Young Ascetic) first appeared in the Nepali literary scene in the year 1953. The work is an extended narrative in 19 cantos which centres around a lovelorn poet, who in his despondency finds himself seeking shelter under a giant tree where a renunciant saint (sadhu) appears before him.

- A long drenched monsoon day

- When the sun careened a little in the western horizon

- Strolling through the untrodden path

- A poet sought shelter beneath a tree

As the poem progresses, the poet as well as the readers come to an awareness that the saint happens to be the spirit of the very tree under which the poet is reposing. The saint delivers a long homily to the mourning poet, recounting and reflecting on his own life riddled with hardships. The poem operates at two different levels; literally it can simply be read as an unmediated account of the world as seen by the tree. However, a more symbolic or allegorical reading of the text provides some very useful insights into issues like human-environment relationship, life, happiness, existence, and above all,death. Rooted at a fixed spot as a tree, the saint tells the poet that his life journey has not been an easy one. As a tiny sapling he had to fight for his survival against rough winds, parasitic pests, grazing animals and self-indulgent humans. The following quatrain aptly captures humans' indifferent attitude towards nature and nature's agony which is too loud to be unheeded.

- With sight swaying neither left nor right

- The ignorant human recklessly stomps ahead

- I tremble, and beseech

- Be mindful of the lives crushed beneath your feet.

The poet effectively uses the poetic device of personification and presents nature as an affected speaking voice which helps him to vouch for a holistic worldview of the universe where there should be a symbiotic relationship and interdependency among every constituent part, including humans. The tree further asserts that everything in this world is bound by a divine spirit. However, human self-centeredness turns a blind eye towards those which are non-human.

- $\quad$ Birds, bees, flowers and trees

- Are all bound by a spirit divine

- When life flutters in all, Why then do you falter?

- Rinse the whole earth with meditated wisdom.

Dodging all hardships, his perseverance and good fortune helped him survive and sustain. As a watchful observer 
of those who took shelter under him enabled him to learn a great deal about the way of the world. At times he has been an eavesdropper to those who sought shelter under him; many a time she has been an unfortunate witness to gruesome human atrocities towards nature. Thus after years of observation and contemplation, he has achieved spiritual enlightenment. One of the most poignant instances of human cruelty against nature is depicted in canto six when a hunter arrives and makes an innocent bird his prey for sport. The dying bird's dolorous final words strike a cogent blow to the ever pervasive yet often unstated anthropocentric human attitude.

- When the fatal arrow pierced the body

- The bird released a helpless wail

- $\quad$ "My time has come but O human, Where has your humanity gone

- Contemplate on its whereabouts".

The dying bird poses a series of stirring questions for which the obvious answer would be negative yet the irony remains that the hedonistic humans go to any extent to gratify their otiose droll. The following lines constitute just a conservative account of the poem's horrors.

- My teardrops will not quench your thirst

- My flesh cannot sustain you for a day,

- $\quad$ Nor can my feathers clothe you

- Why then, did you waste

- This precious life of mine?

The tree expresses its perplexity at the sight of humans garnering its fruits only to be brought back and hawked under the same tree. The sage wonders why such devotion do humans display in uselessly amassing money when it cannot be bitten, is devoid of taste; nor does it impart any wisdom, strength or peace of mind, nor can it be used to warm or satiate their hunger. Why then such stampede for money? The sage questions

- Devoid of any taste and flavour nor can it be bitten

- Nor does it impart wisdom, strength or a certain peace of mind

- It neither warms nor feeds your hunger

- Why then do you uselessly amass with such devotion?

Human existence for the poet as well as the sage is so ephemeral that conceitedness ultimately proves unavailing. Death, the great settler settles everything. Selling one's soul in pursuit of earthly pleasures would eventually be compensated by death. It is death which laughs the last laugh. The following lines aptly rationalize how human self-centeredness meets its tragic end at the hands of mighty death.

- Let me alone gorge in life's pleasures

- While the weak perish in my service 
- Such proud ego bewilders

- $\quad$ And makes the pyre chuckle out a fearless laughter.

The eco-conscious poet asserts with certitude how the anthropocentric worldview has led to the moral degeneration of man and the resultant vitiation of the physical environment. Tarun Tapasi encompasses a wide array of themes ranging from Vedic philosophy, environmental concerns, man's relationship with nature, social issues, existential dilemma to spell out a few. True it is that great literature has a trans-cultural and trans-linguistic significance. It opens up ever new avenues, it illumines the mind; the more we tread into it still more remains to be trodden.

\section{REFERENCES}

1. Buell, Lawrence, (2005). The Future of Environmental Criticism. Chicester, UK: John Wiley and Sons Ltd. Print.

2. Garrard, Greg, (2004). Ecocriticism. New York: Routledge. Print.

3. Anil Kumar Singh, A. P. Singh, Naveen Gaurav, Abhishekh Srivastava \& Arun Kumar, "Morphology \& Ecology of Selected BGA (Aulosira, Tolypothrix, Anabaena, Nostoc) “, International Journal of General Medicine and Pharmacy (IJGMP)), Vol. 5, Issue 3,pp. $37-46$

4. Glotfelty, Cheryll, and Harold Fromm (Eds), (1996). The Ecocriticism Reader: Landmarks in Literary Ecology. Athens, Georgia and London: University of Georgia Press. Print.

5. Mohammed Ali Nause Russel, Mizuki Nakama \& Mohammad Solaiman, "A Comparative Analysis of Revenue Ecology and Decentralization of Service Delivery of the Local Government inBangladesh on Asian Perspective “, International Journal of Accounting and Financial Management Research (IJAFMR), Vol. 5, Issue 4, pp. 7-18

6. Love, A. Glen (2003). Practical Ecocriticism: Literature, Biology and the Environment. US: University of Virginia Press. Print.

7. Ishfaq Hussain Malik, "Socio-Economic, Political and Ecological Aspects of Ecotourism in Kashmir “, BEST: International Journal of Humanities, Arts, Medicine and Sciences (BEST: IJHAMS), Vol. 3, Issue 11, pp. 155-166

8. Poudyal, Lekhnath, (1999). Tarun Tapasi [The Young Ascetic]. Lalitpur, Nepal: Sajha Prakashan. Print 